\title{
MONITORING THE PERFORMANCE OF SET LONGLINES FISHING VESSELS AT FISHERIES MANAGEMENT AREA 718 INDONESIA
}

\author{
Pemantauan Perikanan Rawai Dasar di Wilayah Pengelolaan Perikanan Negara Republik \\ Indonesia 718
}

Author:

Yaya Hudaya ${ }^{*}$, Ilham¹, Sutriyono ${ }^{1}$, Mohamad Natsir²

1Directorate of Fish Resources Management, Directorate General of Capture Fisheries, Ministry of Marine Affairs and
Fisheries of the Republic of Indonesia, at Medan Merdeka Timur No.16 Jakarta.red3mbe@gmail.com,
ilhamkkp11@gmail.com, trikroya@gmail.com.
${ }^{2}$ Center for Fisheries Research, Ministry of Marine Affairs and Fisheries of the Republic of Indonesia.natsir@kkp.go.id.

*Correspondence: red3mbe@gmail.com

Recieved: August 25 th 2021; Approved: November 11 ${ }^{\text {th }} 2021$

\begin{abstract}
Catches reports from set longlines fishing vessels in the fisheries management area (FMA) 718 have been entered into the logbook reporting system since 2012. These vessels targeted reef and demersal fish. Set longlines is considered to be very efficient and productive for catching reef fish. This study aims to see the performance of set longlines vessels. The indicators used are CPUE and fuel efficiency. The results of the study show that the performance of set longlines vessels in the area is getting better and more efficient. One of the indicators of the efficiency is the decreasing the number of fuels to get 1 ton of fish if we compare from year 2014 until 2020.
\end{abstract}

Keywords: CPUE; efficient; fuel; reef fish; set longlines.

\section{ABSTRAK}

Laporan hasil tangkapan kapal penangkap rawai dasar di wilayah pengelolaan perikanan (WPP) 718 telah dimasukkan ke dalam sistem pelaporan logbook sejak 2012. Kapal-kapal rawai tersebut menargetkan ikan karang dan ikan demersal. Rawai dasar dianggap sebagai alat tangkap yang sangat efisien dan produktif untuk menangkap ikan karang. Penelitian ini bertujuan untuk melihat kinerja kapal rawai dasar. Indikator yang digunakan adalah CPUE dan efisiensi bahan bakar. Hasil penelitian menunjukkan bahwa kinerja kapal rawai dasar di daerah tersebut semakin baik dan efisien. Salah satu indikator adalah menurunnya jumlah BBM yang diperlukan untuk memperoleh 1 ton ikan dari tahun 2014 sampai dengan tahun 2020.

Kata kunci: CPUE; efisien; bahan bakar; ikan karang; rawai dasar

\section{INTRODUCTION}

Indonesia as the largest archipelagic country in the world has tropical fish resources. Capture fisheries in Indonesia was dominated by small scale, multi species and multi gear fisheries (Halim et al. 2018). The characteristics of multi-species and multi-gear in
Indonesian waters are a challenge in controlling fishing efforts specifically. Therefore, Indonesia uses a fishing license instrument as a control measure. In adaptive management framework for data fisheries, the cycles consist of data collection, assessment, setting up management measures and monitoring (Dowling et al. 2015). 
Monitoring is needed to control fishing efforts. Since, Indonesia using license instrument to control the utilization of fish resources, hence, the permit must at least contain the name of the vessel, GT, main engine number, radio call, fishing gear, fishing location, and fishing base. However, fisheries management is not only a control aspect but must be able to develop a system of data collection, monitoring, supervision, and law enforcement. These aspects of management are interrelated.

Monitoring the utilization of fish resources in Indonesia is carried out using a reporting system for fish catches, vessel departure data, and others, where catch report using fishing logbook form that has been running since 2012. Since 20172017 an e-logbook application was developed, one of the purpose is to make the form simpler and paperless. This e-log book system is more advance the early development of e-logbook system was developed by Nugroho et al. (2015), it is integrated with the vessel monitoring system (VMS). The reported setting coordinates are validated against the VMS position with a tolerance of 1 degree both latitude and longitude, detailed e-log book integration with VMS was described by Nugroho et al. (2013). In addition, monitoring of vessel departures is very important to determine the efficiency of fishing associated with the use of diesel fuel. This vessel's departure data containing fishing supplies are recorded in the fish landing system and fishing port by the harbormaster.

Currently, there are 5,521 units of fishing vessels above 30 GT operated in Indonesia waters. They are scattered throughout the fisheries management areas located in fishing areas 57 and 71, which are further divided into 11 areas, namely FMA 571, FMA 572, FMA 573, FMA 711, FMA 712, FMA 713, FMA 714, FMA 715, FMA 716 and FMA 718. FMA 718 located in Arafura and Timor Sea, The FMA 718 has very high productivity and very potential for pelagic, demersal, reef fish, shrimp, and others. According to Suman et al. (2018) FMA 718 has the highest fish resources potency compared to others FMA's and contribute more than $21 \%$ from the total Indonesian yearly fish resources potency. With total area about $889,031 \mathrm{~km} 2$, this area belongs to the shallow water category with a depth of $<200$ meters, and has two marine protected areas, namely the Aru Islands MPA and Kolepom MPA.

Several studies about the management policy, especially demersal fisheries have been conducted in Arafura waters. Prisantoso and Badrudin (2010), Badrudin and Aisyah (2009), and Nuraini and Ernawati (2009) discuss and propose the management policy concerning red snapper in Arafura, while Purwanto and Nugroho (2010) and Sari et al. (2018) describe bioeconomy for multigear multispecies demersal fisheries in Arafura Sea. Mahulette and Samu-Samu (2014) emphasize the institutional strengthening Arafura fisheries resources management.

Since 2013, vessels > 30 GT have dominated fishing in FMA 718 that covers the waters of the Aru Sea, Arafura Sea, and the East Timor Sea. One of the fishing gear used in FMA 718 is set longlines. This fishing gear has been operating since 2008 even in previous years. The use of set longlines for vessels over $30 \mathrm{GT}$ is regulated by the Minister of Marine Affairs and Fisheries. The 2011 regulation limits the maximum number of 2,000 hooks and size number 6 and must operate over 12 nautical miles from the coast. Regulations changed in 2016 and 2020, allowing a maximum number of 10,000 hooks.

The number of set longlines vessels operated in FMA 718 are about $100-150$ vessels for more than 10 years. Before 2014, set longlines vessels competed with fishing and shrimp trawlers. After 2015, set longlines must survive and compete with drifting gill nets and purse seiners. The adaptability of set longlines vessels is thought to be because they are more fuel-efficient (Setyorini et al. 2009). The prices of the main target fish include snapper, grouper, pomfret, and jack are much higher than other pelagic and demersal fish.

These set longlines vessels also induce impacts on targeted and non-targeted species. The level of snapper and grouper exploitation in FMA 718 is very high. The evidence is the spawning potential ratio (SPR) $<25 \%$ for Lutjanus malabaricus, Pristipomoides multidens, Lutjanus sebae, Epinephelus areolatus, Lutjanus russelli, Epinephelus coioides, Lutjanus johnii, Lutjanus vitta (Satria et al. 2021). Set longlines vessels make a significant contribution to shark fishing, and there are 20 families recorded, including the hammerhead shark, this high composition of shark also reported by Suprapto (2008).

The objectives of this study are as follows review set longlines performances using logbook data, and asses the longline fleet efficiency in term of fuel consumption. Fish resources utilization monitoring based on fishing ground/FMA, the number of vessels, fishing gear, catch composition, and fuel 
efficiency is very important. Vessel licensing, departure, logbook, and VMS data can be integrated, processed, analysed, and published periodically. The results of this study offer a choice of analysis that can be presented in monitoring the use of fish resources. Moreover, it is used to ensure the level of utilization, efficiency, and impacts of the fishing activities, especially by the set longline fishing fleet in FMA 718, and provide robust information and inputs for fisheries management.

\section{METHODS}

We gathered data from logbook and elogbook programs from the fishing port information center of the Ministry of Marine Affairs and Fisheries for 2013 - 2020. The scope of the research is the fishing vessels using set longlines and over 30 GT. The research location focuses on FMA 718 Indonesia. Collected logbook data consisted of the weight of fish caught, setting position based on species name, fishing ground, and fishing gear.

Data were downloaded from the Pusat Informasi Pelabuhan Perikanan (PIPP) database system, provided by Fishing Port Directorate - DGCF. The downloaded results were processed in the Microsoft Access 2013 software (15.0.5267.1000) and Excel 97-2003. Other tools applied were Power $\mathrm{Bl}$ version: 2.88.1682.0 64-bit which was used for data integration and querying. This study also used several references, especially the fish base database, to clarify fish families and their ecology.

The data that has been available in the form of excel files and access which is then processed using power BI. These data are important elements that can be used in monitoring the use of fish resources. These data include maps of fishing areas, CPUE, fish composition, and fuel efficiency. Several graphs and curves such as CPUE curve, fuel efficiency, fish composition graph generated using excel software.

Fish distribution map according to the coordinate settings in the logbook and then plotted with the map available on the Power BI visualization menu. In addition, annual data visualization is easier to do in Power BI. The CPUE calculation is carried out using simple process and equation so that it is easily accessible by the fishing community, namely by dividing the number of fish caught (tons) per trip by the number of fishing vessels whose licenses were issued in that year.

CPUE = Catch (ton): Effort (trip)

The results of the CPUE calculation are then compared to the total set of longlines fishing vessels above 30 GT in FMA 718 every year.

The graph of fish composition is done by querying the data on the fish's scientific name from the Power BI per year. After that, the scientific name was validated with fish base data to see the family group. The query process is carried out to obtain catch data per fish family and per year. The graph has been making from excel.

The efficiency curve for the use of fuel oil is obtained by integrating data taken from the logbook system with data from the fishing port information center system. This data processing is rather complicated because it requires several query processes in Power $\mathrm{BI}$. In fact, it is necessary to adjust the fuel data in the database of the fishing port information center using the value of money so that it is converted into fuel volume by dividing it by the average price determined every year. The source of annual price data is obtained through https://solarindustri.co.id.

The fuel efficiency formula is the fuel used (litres) for every 1 ton of fish landed by fishing vessels (Tyedemers 2004). This formula has also been referred to in the guidelines for saving fuel for small-scale fishers (FAO 2012). As a reference results, in Indonesia an example of fuel efficiency study for tuna pole and line and tuna longline was conducted by Suryanto and Wudianto (2017).

\section{RESULTS}

The number of vessels operated in FMA 718 and > 30 GT amounted to 114-164 units per year. In 2013, there were 114 units of fishing licenses and have increased every year (Table 1). The level vessel compliance in reporting fishing logbooks tends to increase year by year from 20\% in 2013 to $82 \%$ in 2020 . In 2020, set longlines vessels reported logbooks amounted to 134 units.

Generally, if we use the median value data set, the set longlines vessels are $65 \mathrm{GT}$. Before 2017, the vessel was 38 GT, but after 2017 there was an increase in the vessel size up to 75 GT (Table 2). We also found that the number of crew on board remains relatively 
constant at 11 people each year. Operation time and catch per trip tend to increase from year to year. In 2013 the time at sea for 36 days increased to 64 days in 2020. Likewise, the catch per trip has increased from 8.05 tons to 20.80 tons in 2020.

The fishing locations for set longlines vessels in the last year (2020) mostly operated around the east, southeast, and south Aru Islands. Others are around Dolak Island to the north, northwest, and south. The location is also near the coastal waters of Papua around Timika (Figure 1). Fishers report the fishing spot through an android-based e-logbook application. This position is validated by the position of the vessel monitoring system (VMS). The coordinates are clustered in a place that can be defined as a fishing ground. There were 3 main fishing grounds detected, namely: (1) $-5.75 \mathrm{~S} 134.23 \mathrm{E}$;(2) $-8.45 \mathrm{~S}$ 136.63 E; (3) $-7.77 \mathrm{~S} 136,77 \mathrm{E}$. Thos three points are located around Aru Island in the Northeast and around Dolak Island in the Northwest. The location of the fishing ground above is already known by fishermen through habits and assistance from GPS devices. Precise location coordinates result in higher target and non-target fish catches. The location of the set longline in this study was similar to the study conducted by Sadhotomo and Suprapto (2013) and Badrudin et al. (2005).
The locations were near the slope, where the deeper water adjacent with shallow water area.

The catch from $2013-2020$ is shown in Figure 2. The highest catch per unit effort (CPUE) of set longline about 24.06 tons per trip, occurred at 132-unit fishing vessels. Figure 2 shows that if the number of permits issued exceeds 132 units, the fish catch tends to decrease. The proportion of snappers and groupers catches in FMA 718 tends to decline from year to year, from $83 \%$ in 2013 to $14 \%$. in 2020. Comparing to the previous results from Suprapto (2008) and Sadhotomo and Suprapto (2013), the catch of snappers and groupers is less than $15 \%$. On the other hand, catches of croackers and others tend to increase from $13 \%$ in 2013 to $83 \%$ in 2020 (Figure 3).

Figure 3 shows that the catch of nontarget sharks and rays is between $1-2 \%$ per trip per year. Ray's catch is less than $1 \%$. Likewise, jacks and pompanos average $3 \%$ per trip per year. Even though the catch of snappers and groupers is decreasing, and other catches are increasing, diesel fuel is getting more efficient. The average use of fuel per tons of fish is 1,253 liters, even in 2020 it is only 1,093 liters per ton of fish (Figure 4). Figure 4 shows that before 2015 fishing using set longlines was very inefficient. The use of fuel at that time ranged from 3,000 to 4,500 liters per tonne of fish.

Table 1 The Number of permits and logbooks for set longlines fishing vessels above $30 \mathrm{GT}$ in FMA 718 (Directorate General of Capture Fisheries)

\begin{tabular}{cccc}
\hline Years & License (unit) & Logbook (unit) & Compliance (\%) \\
\hline 2013 & 116 & 23 & 20 \\
2014 & 122 & 68 & 56 \\
2015 & 118 & 49 & 42 \\
2016 & 114 & 53 & 46 \\
2017 & 132 & 88 & 67 \\
2018 & 126 & 95 & 75 \\
2019 & 150 & 39 & 26 \\
2020 & 164 & 134 & 82 \\
\hline Average & 130 & 69 & 52 \\
\hline
\end{tabular}

Table 2 The Characteristic and performances of set longlines vessels above 30 GT in FMA 718 (Directorate General of Capture Fisheries)

\begin{tabular}{lcccc}
\hline Years & \multicolumn{4}{c}{ Median } \\
\cline { 2 - 5 } & Vessel Size (GT) & Day at sea & Number of Crew & Catch per Trip (Ton) \\
\hline 2013 & 35 & 36 & 10 & 8.05 \\
2014 & 34 & 35 & 10 & 5.35 \\
2015 & 38 & 44 & 10 & 6.99 \\
2016 & 34 & 65 & 11 & 18.22 \\
2017 & 68 & 59 & 11 & 24.06 \\
2018 & 71 & 59 & 11 & 21.34 \\
2019 & 77 & 70 & 11 & 23.02 \\
2020 & 75 & 64 & 12 & 20.80 \\
\hline Average & 65 & 59 & 11 & 19.09 \\
\hline
\end{tabular}




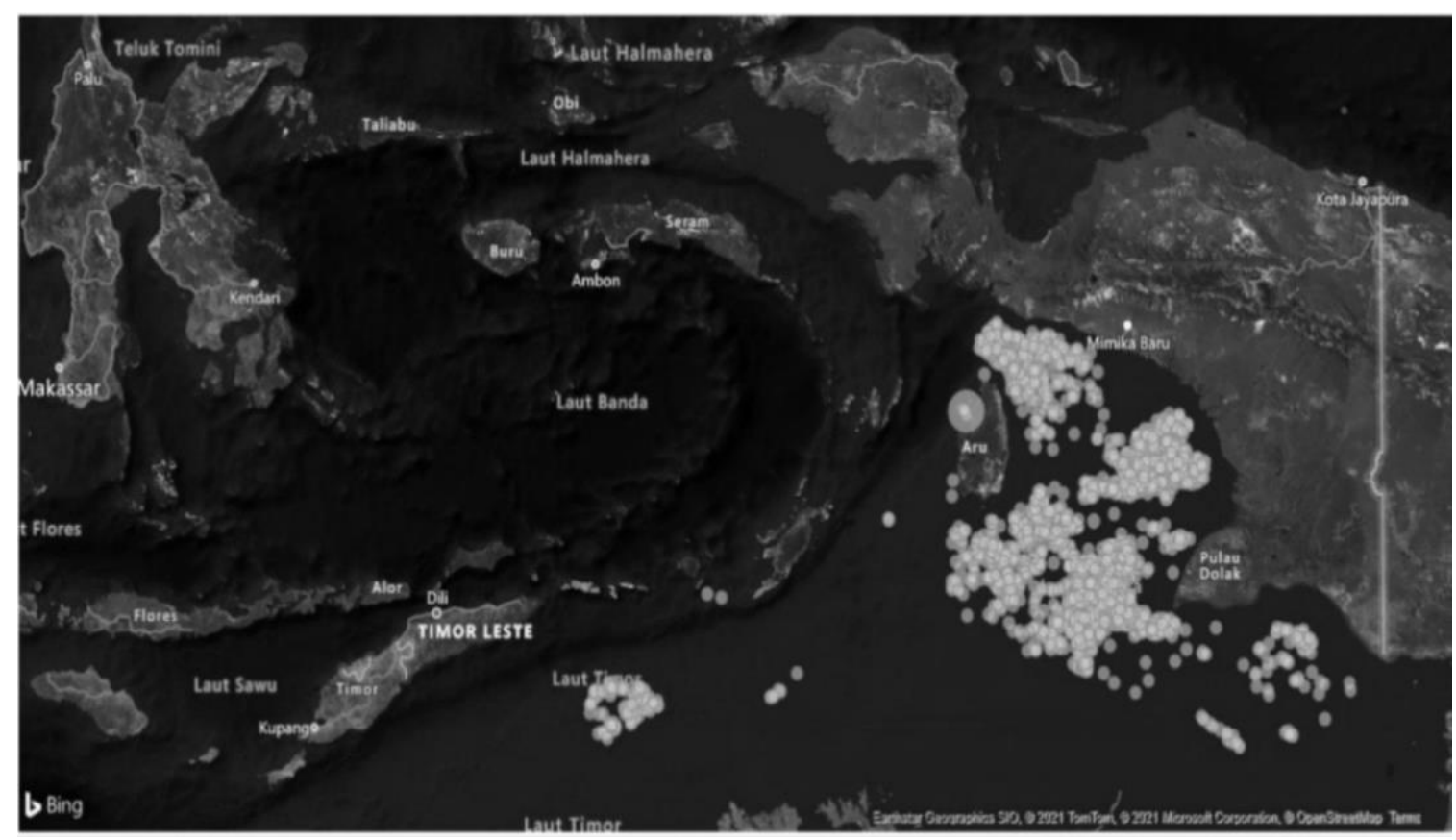

Figure 1 The Fishing ground of set longlines vessels in FMA 718

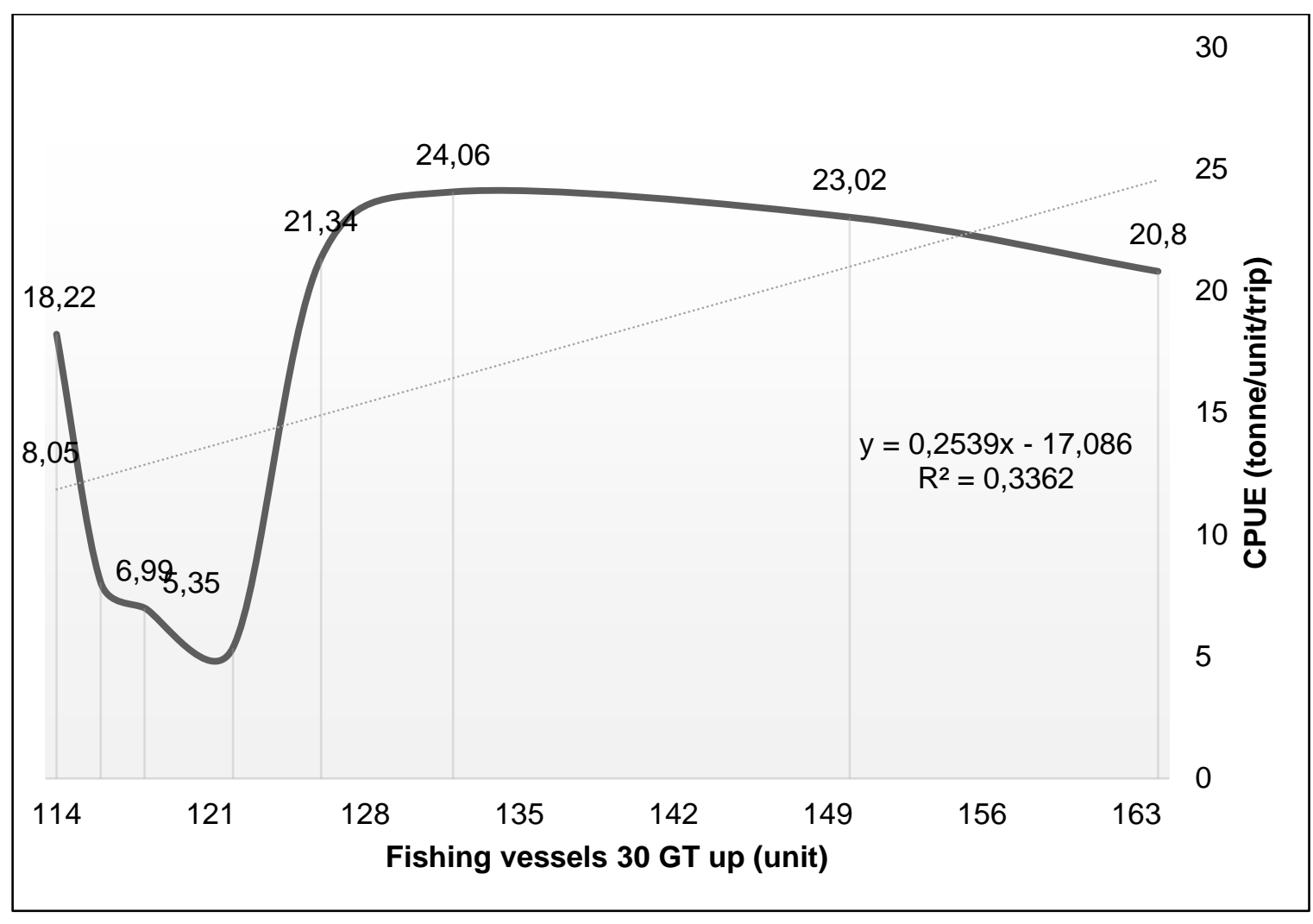

Figure 2 Catch per unit effort set longlines 30 GT up in FMA 718 


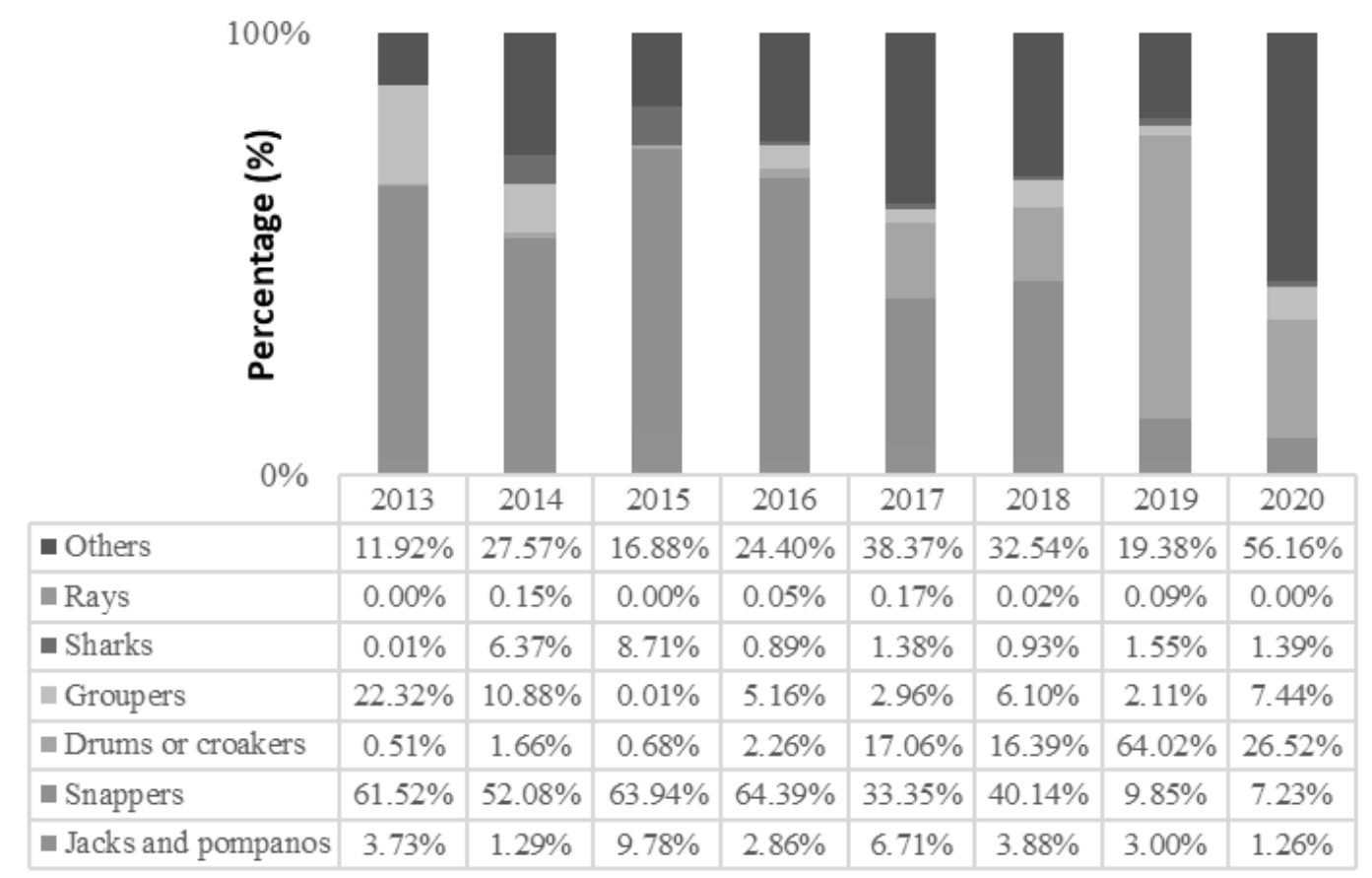

Figure 3 The Shift in catch composition of set longlines in FMA 718

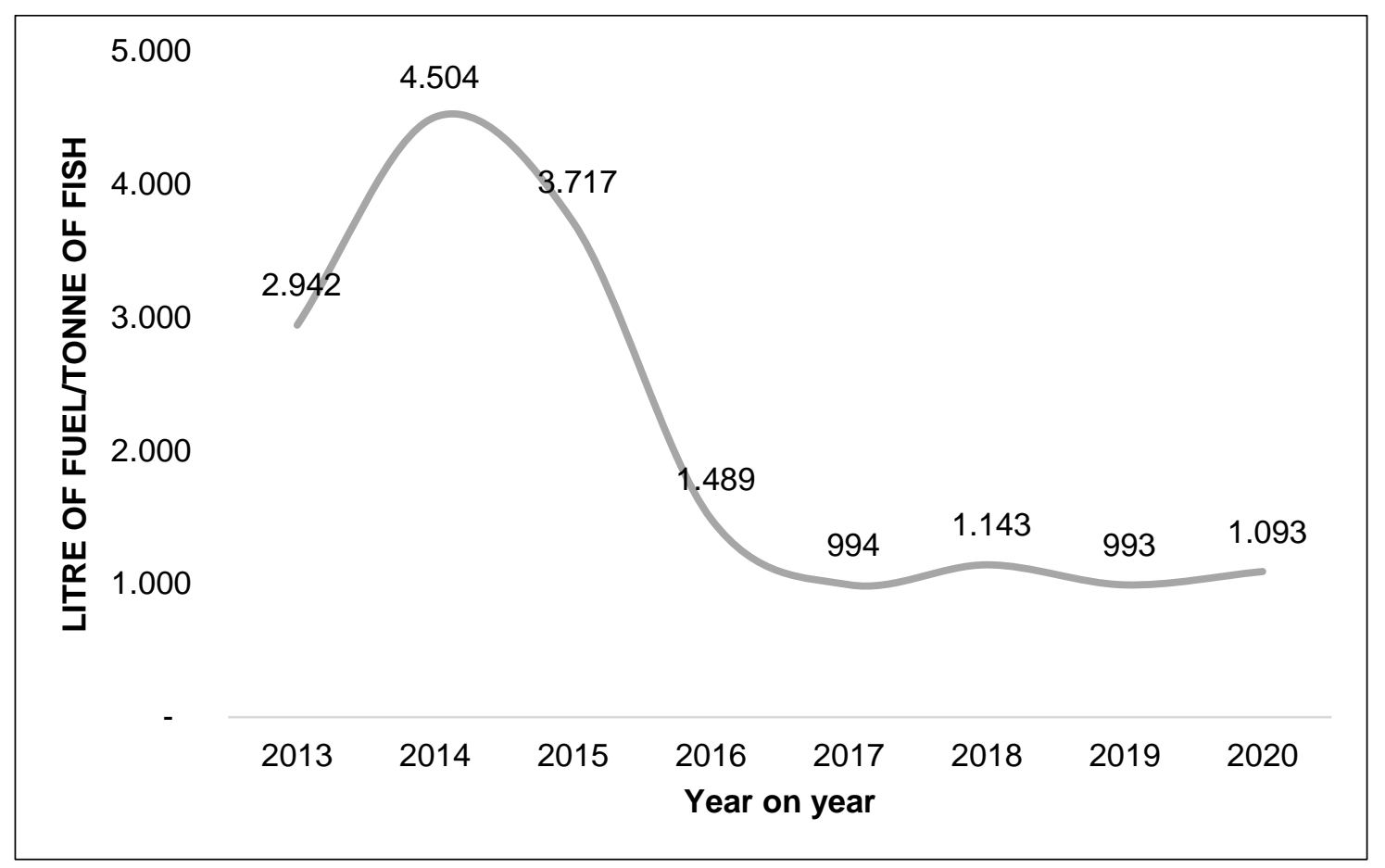

Figure 4 The number of fuel used per tonne of fish

\section{DISCUSSION}

The fishermen want the main target fish catch to be more dominant. The main target of the catch is the family of snappers and groupers because the price per kilogram is higher, so it can cover the cost of fuel each time they go to sea. The fishing data collection system is related to the monitoring system for utilizing fish resources. Data collection and monitoring systems and devices are currently growing rapidly in line with advances in information technology (van Helmond et al. 
2020). In fact, an electronic monitoring system to support fisheries management has been and is being developed (Boenisha et al. 2020 and Natsir et al. 2021). Indonesia continues to develop from the construction of a fishing logbook system in 2010. The development of an e-logbook in 2017 has succeeded in reducing the use of paper in electronic reports. In addition, the level of accuracy and validity of the data, especially the setting position, has been successfully verified.

However, despite the progress of fishing data collection and monitoring systems, a basic substance in such monitoring is needed. The results of this study present several important materials for monitoring the use of fish resources, namely:

1. the number of licensed vessels, number of reported vessels, and level of compliance;

2. the median GT of the ship, day of the sea, crew, and catch per trip;

3. Map of fishing locations for the last year;

4. Fish composition chart based on target and non-target fish families;

5. and the efficiency curve for the use of diesel fuel per trip.

In 2015 there was a significant change in fishing policy. At that time, Susi as Minister of Maritime Affairs and Fisheries, had banned the use of fish and shrimp trawls. In addition, foreign-made fishing vessels are also prohibited from catching fish in Indonesian waters including FMA 718. There are 4 FMA which are the main fishing locations for foreign-made vessels including $711,716,717$, and 718 . The massive use of foreign-made fish trawls and shrimp trawls in FMA 718 has resulted in inefficient fishing for vessel set longlines vessel. This is proven by CPUE and fuel efficiency. Before 2016, fish catches were $<10$ tons per trip by spending 3,000 -4,500 liters of fuel per ton of fish. However, between 2013 - 2015, the catch composition of snappers and groupers reached $>60 \%$ per trip. This is very interesting to be discussed further.

The bycatch of shrimp trawl in FMA 718 reaches $90 \%$, croackers fish (Johnius spp) is very dominant while snapper and grouper are less than 2\% (Umamah, 2017). The ratio of catch to bycatch is 1:12 (Sumiono and Hargiyatno 2012), while snappers are less than 3\% (Djazuli 2009). Before 2015, data shows that snappers and grouperswere caught $53 \%$ by fishing trawlers, $45 \%$ by set longlines, $1 \%$ by drift gill nets, and $1 \%$ by other vessels. In 2016 - 2020 snappers and groupers were caught by $87 \%$ by set longlines, $9 \%$ by drift gill nets, and $4 \%$ by other vessels.

Drums or croackers, jacks and pompanos were caught $95 \%$ by fishing trawlers, $3 \%$ by drift gill nets, $1 \%$ by set longlines, and $1 \%$ by other vessels. After 2015 caught by $55 \%$ by set longlines, $41 \%$ drift gill nets, and $4 \%$ other vessels (logbook). Therefore, until 2015 the capture of snappers and groupers was dominated by trawl and set longlines. Meanwhile, after to 2015, set longlines are dominant fishing gear. The competitions after 2015 were contested by set longlines and drift gillnets, especially for the drums, jack, and pompanos. Drift gillnet in FMA 715 has the ability to catch demersal fish, since in some areas, they have less than 30 meters. Drift gillnet that has 15 meters width can be operated at shallow water $(<30$ meters) and yield demersal fish.

The existence of set longlines vessels after the banning of trawls and foreign-made vessels is very favorable. Set longlines can fish without competing with other fishing gear, hence having better catches for target and non-target fish. Therefore, Susi's policy positively impacts setting longline tending to be more efficient than the previous years. It can be seen from the use of diesel fuel from 2,942 liters in 2013 to 1,093 liters per ton of fish in 2020.

Set longlines more fuel-efficient compared to other fishing gears, dredges and other pelagic gear need higher fuel consumption (Davie et al. 2015). The cost of diesel fuel to the total operational costs of the ship can reach $70 \%$. However, poor monitoring and evaluation of the fishing efforts resulted in a decrease in the set longlines CPUE from 2017 - 2020, particularly for snapper and grouper. Moreover, the composition of snappers and groupers catches also tends to decrease.

The set longlines unit increased from year to year in terms of the number of vessels, size, and sea days. In addition, the increasing number of drift gill nets from 147 units in 2013 to 449 units in 2020 (Directorate General of Capture Fisheries, unpublished data). It can be seen that from 2017 to 2020 , the snappers and groupers in FMA 718 were indicating overfishing. Moreover, the SPR of snappers 
and groupers was $<25 \%$ (Satria et al. 2021), indicating the same condition with other indicators.

The impact of set longlines on the environment is sharks and rays' bycatch. Some species of sharks and rays that Indonesia had regulated are whale shark (Rhincodon typus), manta rays (Mobula birostris and Mobula alfredi), thresher sharks (Alopias spp.), silky shark (Carcharhinus falciformis), oceanic whitetip shark (Carcharhinus longimanus), hammerhead shark (Sphyrna spp.), and mobula rays (Mobula spp.). The catch of sharks and rays by longline vessels is only $1 \%-2 \%$ from reported weight, meaning that if the catch is 20 tons of fish, then sharks and rays will be 200-400 kilograms or 8-16 individuals per landings assuming a weight of $25 \mathrm{~kg}$ per individual. The location for shark catching in 2020 is between Aru Island and Dolak Island or between Aru and Kolepom conservation areas with latitude coordinates $-6--8 S$ and longitude 135 - $138 \mathrm{E}$.

Sharks and rays caught in the period 2013-2020 were dominated by the Carcharhinidae (requiem sharks) family by $70 \%$, Hemiscylliidae (bamboo sharks) 12\%, Lamnidae (mackerel sharks or white sharks) $13 \%$, other sharks $5 \%$. Some of the rays caught were dominant from the Pristidae (Sawfishes) family by $66 \%$, Dasyatidae (Stingrays) $29 \%$, other rays $5 \%$.

The capture of sharks and rays is generally incidental. From this research, the dominant factor causing the catching of sharks and rays remain unknown. In addition, there is no information on the re-release of the captured sharks and rays. However, in general, set longlines vessels use a $\mathrm{J}$ hook type with a size of 6 . According to André et al. (2011) that the use of type J hooks will result in greater mortality when fish are caught before being released again, compared to type $C$ hooks which can release larger sharks alive.

\section{CONCLUSION}

Set longline catch data obtained from elog book could be analyzed as a source of information needed to review the performance and fuel consumption of set longline fishery, this assessment results could be utilized as an input for the fisheries management. Although the accuracy and compliances are still low, it's show an increasing trend. The future work for this study is that further utilization for detailed spatial density catches productivity analysis will be possible using another modelling approach and incorporate the results as management inputs for the fisheries managers.

\section{RECOMMENDATION / SUGGESTION}

In order to get more robust data and analysis results, the utilization of e-logbook for the resource's exploitation monitoring needs to be increased especially the compliance and data accuracy. Its data analysis in other FMA areas and other fishing gears need to be extended to grasp the in-situ condition of the fisheries resources in Indonesia and contribute to sustainable fisheries mana-gement.

\section{ACKNOWLEDGEMENT}

We would like to thank Directorate General of Capture Fisheries (DGCF), Ministry of Marine Affairs Republic Indonesia for e-logbook data and other supporting data i.e., license data, and REKAM Foundation for supporting the data analysis and productive discussion. This study is part of the existing capture fisheries data analysis to increase the contribution for better data collection and analysis to support the fisheries management. This study is part of the existing capture fisheries data analysis to increase the contribution for better data collection and analysis to support the fisheries management.

\section{REFERENCES}

André SA, Fábio HVH, Felipe $C$, José $C P$, Humberto H, David WK, Debra M, George HB. 2011. Fishing Gear Modifications to Reduce Elasmobranch Mortality in Pelagic and Bottom Longline Fisheries off Northeast Brazil. Fisheries Research. 108 (2-3): 336343.

Badrudin, Wiadnyana NN, Wibowo B. 2005. Deep.Water Exploratory Bottom Long Lining in the Waters of the Arafura Sea. Indonesian Fisheries Research Journal. (11): 41-46.

Badrudin, Aisyah. 2009. Separate Stocks of Red Snapper Exploitation and 
Management in the Indonesian Sector of the Arafura Sea. Indonesian Fisheries Research Journal. 15(2): 8188.

Boenisha R, Willard D, Kritzera JP, Reardon K. 2020. Fisheries monitoring: Perspectives from the United States. Aquaculture and Fisheries. (5): 131138.

Davie S, Minto C, Officer R, Lordan C, Jackson E. 2015. Modelling Fuel Consumption of Fishing Vessels for Predictive Use. ICES Journal of Marine Science. 72(2): 708-719.

Djazuli N. 2009. Analysis of Surimi Processing Industry Development in Utilizing Shrimp Trawl By-Catch [Ph.D. Dissertation]. Bogor Agricultural University.

Dowling N, Dichmont CM, Haddon M, Smith DC, Smith ADM, Sainsbury K. 2015. Guidelines for Developing Formal Harvest Strategies for Data-Poor Species and Fisheries. Fisheries Research. (171): 130-140.

[FAO] Food and Agriculture Organization of The United Nations. 2012. Fuel Savings for Small Fishing Vessels A manual. Rome.

van Helmond AT, Mortensen LO, Plet-Hansen KS, Ulrich C, Needle CL, Oesterwind D, Kindt-Larsen L, Catchpole T, Mangi S, Zimmermann C, Olesen HJ. 2020. Electronic Monitoring in Fisheries: Lessons from Global Experiences and Future Opportunities. Fish and Fisheries. 21(1): 162-189.

Halim A, Wiryawan B, Loneragan NR, Hordyk A, Sondita MFA, White AT, Koeshendrajana S, Ruchimat T, Pomeroy RS, Yuni C. 2018. Developing A Functional Definition of Small-Scale Fisheries in Support of Marine Capture Fisheries Management in Indonesia. Marine Policy (100): 238-248.

Mahulette RT, Samu-Samu A. 2014. Strengthening Institutional to Support Fishery Resource Management In the Arafura Sea. Jurnal Kebijakan Perikanan Indonesia. 6(2):87-96.
Natsir M, Waryanto, Wada M. 2021. An Attempt of Digitalization Bali Strait Purse Seine Capture Fisheries Data. IOP Conf. Series: Earth and Environmental Science. 674 (2021) 012066. https://doi.org/10.1088/17551315/674/1/012066.

Nugroho H, Sufyan A, Akhwady R. 2013. Integration Between Electronic Fishing Log Book Systems with Vessel Monitoring System for Sustainable Fisheries Development. Jurnal Kelautan Nasional. 8(3): 101-110.

Nugroho H, Sufyan A, Wiadnyana NN. 2015. The Application of Fishing Electronic Logbook to Support Fisheries Management. Jurnal Kelautan Nasional. 10(3): 113-124.

Nuraini S, Ernawati T. 2009. Changes to the Red Snapper Fisheries in the Arafura Sea Fisheries Management Area. Indonesia Fisheries Research Journal. 15(1): 9-16.

Prisantoso BI, Badrudin. 2010. Kebijakan Pengelolaan Sumber Daya Ikan Kakap Merah (Lutjanus Spp.) di Laut Arafura. Jurnal Kebijakan Perikanan Indonesia. 2(1): $71-78$

Purwanto, Nugroho D. 2010. The Optimum Level of Shrimps, Demersal and Small Pelagic Fish Resource Exploitation in Arafura Sea. Jurnal Penelitian Perikanan Indonesia. 16(4): 311-321.

Sadhotomo B, Suprapto. 2013. Interaction Between Trawl and Bottom Longline of Red Snapper (Lutjanus Malabaricus) Fisheries in the Timor and Arafura Sea. Jurnal Penelitian Perikanan Indonesia. 19(2): 89-95.

Sari YD, Syaukat Y, Kusumastanto T, Hartoyo S. 2018. Management of Demersal Fishery in the Arafura Sea: A BioEconomic Approach. Jurnal Sosial Ekonomi Kelautan dan Perikanan. 13(1): 43-57.

Satria F, Mous PJ, Perdanaharja G, IGede WB. 2021. Long-Based Stock Study of Species Captured in the Deep Sea in Demersal Fisheries Targeting Snapper in FMA 718 [Report]. Marine Fisheries 
Research Institute. Center Fisheries Research. Indonesia.

Setyorini, Suherman A, Triarso I. 2009. Comparative Analysis of Bottom Set Long Line and Boat Seine Fishing Effort Productivity In Juwana, Pati Regency Jurnal Saintek Perikanan. 5(1): 7-14.

Suman A, Satria $F$, Nugraha B, Priatna A, Amri K, Mahiswara. 2018. The Stock Status of Fish Resources in 2016 at Fisheries Management Area of Indonesian Republic (FMAS) and Its Management Alternative. Jurnal Kebijakan Perikanan Indonesia. 10(2): 107-128.

Sumiono B, Hargiyatno IT. 2012. Shrimp ByCatch and Alternative Utilization in the Arafura Sea. Journal of Indonesian Fisheries Policy. 4(2): 85-91.
Suprapto. 2008. Keragaan Penangkapan Ikan Demersal di Kawasan Timur Indonesia yang Berbasis di Probolinggo. BAWAL Widyariset Journal: 2(3): 123-131.

Suryanto, Wudianto. 2017. Estimation Model of Fuel Consumption for Pole- Line and Longline Fishing Vessels. Jurnal Penelitian Perikanan Indonesia. 23(2): 99-110.

Tyedemers P. 2004. Fisheries and Energy Use. Encyclopedia of Energy. Page: 683-693. Elsevier. The Netherlands.

Umamah M. 2017. Sustainable Management of Shrimp Resources in the Aru and Arafura Seas [Master Thesis]. Bogor Agricultural University. 